\author{
Asian Development Policy Review \\ $\operatorname{ISSN}(e):$ 2313-8343 \\ $\operatorname{ISSN}(p): 2518-2544$ \\ DOI: $10.18488 / 5008 . v 10 i 1.4398$ \\ Vol. 10, No. 1, 16-34. \\ (C) 2022 AESS Publications. All Rights Reserved. \\ URL: www.aessweb.com
}

\title{
HOW DIFFERENT DRIVERS OF LIABILITY OF FOREIGNNESS AFFECT EMNES ASYMMETRICALLY AT THE PRE-M\&A STAGE: STATIC AND DYNAMIC VIEWS
}

Hua Zhu' Yi Qu ${ }^{2+}$

\author{
${ }^{\prime}$ School of Business Administration, Dongbei University of Finance and \\ Economics, Dalian, China. \\ Email:zhuhua@dufe.edu.cn Tel :008613940938949 \\ 'Surrey International Institute, Dongbei University of Finance and \\ Economics, Dalian, China. \\ Email:quyijerry@dufe.edu.cn Tel:o08618624363658
}

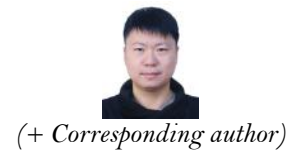

(+ Corresponding author)

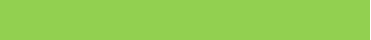

Article History

Received: 8 November 2021

Revised: 17 December 2021

Accepted: 28 December 2021

Published: 14 January 2022

\section{Keywords}

Cross-border M\&A

Pre-acquisition stage

Liability of foreignness

Organizational learning

Context/Content-related

experience

SOE identity.

JEL Classification:

D22 F23 G34.
ABSTRACT

This study investigates how the drivers of liability of foreignness (LOF) influence the likelihood of emerging multi-national companies completing overseas acquisition deals and explores contingencies that moderate the adverse effects of LOF from both static and dynamic perspectives. We test our hypotheses and find that (1) statically, the formal institutions of laws and regulations per se as well as culture distance are sources of LOF, rather the distance between the laws and regulations of home and host countries. (2) Organization-inherent characteristics, like an industry that may trigger legitimacy concerns, have moderating effects on LOF, while state-ownership is not proved to be a significant moderating factor. (3) Dynamically, different drivers of LOF exert asymmetric effects on firms with prior international experience: cultural distance ceases to exert a significantly negative influence on the completion of acquisitions, but the negative effect stemming from formal institutions is reinforced.

Contribution/ Originality: This study is one of very few to investigate how the drivers of liability of foreignness influence the likelihood of emerging MNCs completing overseas acquisition deals, and to explore the contingencies that moderate the adverse effects of LOF from both static and dynamic perspectives.

\section{INTRODUCTION}

Overseas mergers and acquisitions by Chinese enterprises have been increasing rapidly in the past decades. More and more enterprises are employing cross-border mergers and acquisitions (CBMAs) to obtain strategic assets or to expand into new markets to enhance their international competitiveness in a short period of time. The rapid expansion of Chinese enterprises' outward foreign direct investment (OFDI) in the world market has received a great deal of academic attention. Scholars have shown great interest in the phenomenon and have explored various features of Chinese OFDI, such as the trends and driving forces (Morck, Yeung, \& Zhao, 2008; Yang, Jiang, Kang, \& Ke, 2009), the determinants (Buckley et al., 2007; Kolstad \& Wiig, 2012), the motives (Child \& Rodrigues, 2005; Rui \& Yip, 2008), and the entry modes (Cui \& Jiang, 2009; Meyer, Estrin, Bhaumik, \& Peng, 2009). Although Chinese enterprises' CBMAs are in a booming period of development, according to a report by the Boston Consulting Group, their completion rate is only $67 \%$, which is far below that of their counterparts from the United 
States, Japan, and other developed countries. ${ }^{1}$ The acquisition process consists of two phrases: the private takeover process and the public takeover process (Boone \& Mulherin, 2007). The private takeover involves the process of identifying the targets through diligent investigation along with the assistance of legal and financial advisors, negotiating with the seller along with other bidders, and making the public announcement of the offer when the initial contract is signed. The public takeover process is the public announcement session in which the market and stakeholder receive the information and is, in most cases, subject to government approval. Normally, a CBMA case will undergo investment barriers at this stage, such as a national security review, market monopoly investigation, industry access restrictions, and various kinds of recognition of stakeholders. It is worth clarifying that the failure of a merger and acquisition intention refers to cases in which companies have announced their intentions for a foreign enterprise's equity, but have failed to reach an agreement. In other words, failures occur in the public takeover period. The pre-stage of a CBMA is of great importance to a multinational enterprise, because the failure of the takeover will not only waste the substantial costs they incurred in the private takeover stage and the opportunity cost in acquiring the equivalents, but also damage the firm's reputation and credibility (He \& Zhang, 2018; Li., Xia, \& Lin, 2017).

The growing literature provides a number of reasons why CBMAs fail at the initial stage, such as geographic distance (Chakrabarti \& Mitchell, 2016); timing of the transaction in the wave (Doan, Rao, \& Van, 2016); lack of prior divestiture experience (Doan, Sahib, \& van Witteloostuijn, 2018); or deal-level factors, such as percentage of stake or cash transactions (Zhou, Xie, \& Wang, 2016); state-ownership identity of the acquirers (Li et al., 2017); and the adverse institutional image for investors from developing countries (He \& Zhang, 2018). In this study we try to address the problem from a liability of foreignness (LOF) perspective, rooted in institutional theories (Denk, Kaufmann, \& Roesch, 2012; Pogrebnyakov \& Maitland, 2011).

This paper aims, firstly, to unpack the drivers of LOF toward emerging multi-national enterprises (EMNEs) and reveal which dimension results in a greater extent of LOF compared to the others; secondly, to explore to what extent these sources affect EMNEs, contingent upon organizational-inherent characteristics, as emerging multinational corporations (EMNCs) compete in a resource-deficient position. In other words, the organizational static state of identity and dynamic state through accumulation of experience may have moderating effects on the degree of vulnerability to LOF.

This study tries to contribute to the literature in the following ways. First, the pre-entry stage can provide a better perspective from which to observe LOF. In practice, the study of pre-acquisition performance is imperative not only due to the high failure rate of Chinese CBMAs, but also because the pre-acquisition stage is a complex business process that requires due diligence, bidding and approval by the host country, which will determine the successful completion of the CBMA cases. Theoretically, we assume that pre-acquisition is an appropriate stage in which to study LOF. The extant research focuses mostly on the extent of LOF's influence on the performance of firms, for instance in terms of survival rate, profitability and returns, or probability of lawsuits (Li, Meng, Wang, \& Zhou, 2008; Miller \& Eden, 2006; Zaheer \& Mosakowski, 1997). It is arguably beneficial to employ the financial performance of subsidiaries to measure the influence of LOF, as the profitability can not only be affected by firmspecific advantages but also internal price or profit transfer strategy. Thus, we have chosen the pre-acquisition stage as the context of the study to wipe out the "noisy" variables, because in this stage the objective of M\&A is quite simple and clear - the consummation of the deal - and will not be confused with other strategic intents.

Second, while the static picture of LOF prevails in the literature, our knowledge regarding the dynamics of LOF is still limited. Although the institutional environment per se is relative stable over time, reflecting the idiosyncratic context of the local market that FDI is subject to North (1990); Peng, Sun, Pinkham, and Chen (2009), we argue the outcome of interactions between MNEs and the institutional environment is both firm-specific and

'The Economist. The New Colonialists; China's Hunger for Natural Resources [Online]. Available at http://www.economist.com/node/10853534[accessed : March 13 2008]. 
dynamic. From a static point of view, we added the inherent characteristics that might enhance the adverse effects of LOFs, which cannot be overcome. From a dynamic perspective, we try to explore how different shades of experience can cope with the different dimensions of LOF's sources to help investigate the mechanism of effective organizational learning activities. Further, in contrast to prior literature that used the total number of global operational identities or the count of different countries operated in as a proxy to measure the degree of international experience (Mezias, 2010), our nuanced categorization of experience is based on the calculation of the environment proximity and FDI patterns, to tackle the problem of lack of experience on the part of EMNEs.

Third, it is worth noting that a variety of research efforts has been shown to exhibit bias toward MNEs from developed countries (Denk et al., 2012; He \& Zhang, 2018), while emerging MNCs (EMNCs) that suffer many disadvantages are worthy of particular attention. Despite the additional costs of doing business compared to indigenous firms, EMNCs also lack well-known brand names and cutting-edge technologies, and what is even more challenging is that they bear the negative national and institutional image of their home country (Bartlett \& Ghoshal, 2000; He \& Zhang, 2018). Hence, EMNCs experience more difficulties combatting LOF, and the ways in which they overcome their initial disadvantages when entering the global marketplace is of increasing importance to IB theories.

\section{THEORETICAL BACKGROUND AND HYPOTHESES}

\subsection{The Drivers of Liability of Foreignness}

The "liability of foreignness" (LOF) concept was introduced by Hymer (1960), suggesting that foreign companies have disadvantages compared to local firms due to their inexperience with the business conditions of foreign markets, which can be considered additional "rent" expenditures. LOF is considered to be major hurdle to the successful establishment of foreign operations (Johanson \& Vahlne, 2009). Therefore, MNEs will employ their proprietary assets to offset LOF and rely on their "net competitive advantages" (Dunning, 1979) to stabilize their footprint. However, for EMNCs, specific ownership advantages such as labor resource advantages may fail to contribute. Even worse, some advantages, such as relational assets, turn to disadvantages in host countries.

Despite the fact that MNCs go to great efforts to accommodate the local environment, for instance by identifying special preferences of the target market or exploring new market channels, the host country's culture and specifically tacit knowledge remains less identifiable to them (Kostova \& Zaheer, 1999) and thus cultural distance influences the degree of LOF (Eden \& Miller, 2004).

Even when they eventually figure out how local managerial practices work, it is still very difficult to implement them, due to their lack of comprehension (Edelman, 1990). As the main task of the pre-acquisition stage is to collect reliable information on the target firm in a timely manner under competitive circumstances (Jemison \& Sitkin, 1986; Very \& Schweiger, 2001), the ambiguity stemming from culture will not only result in higher costs associated with scanning, analyzing and understanding the information, but will also cause conflicts between the parties, which will slow down the pace of the negotiation of the deal. Hence, entering into culturally similar country blocs entails less additional cost for foreign entrants; otherwise, MNCs need cultural sensitivity to resolve incompatibilities caused by informal or tacit constraints (Dikova, Sahib, \& Van Witteloostuijn, 2010; Morosini, Shane, \& Singh, 1998). Where there are large cultural differences, CBMAs at the negotiation stage are more likely to be subject to failure or abandonment. Thus, we propose

\section{H1a: Cultural distance negatively influences the realization of MNEs' CBMA intentions.}

An institution is a system that consists of regulations and norms, and a complete institutional framework is composed of the formal and informal institutions that dominate personal and corporate behaviors (North, 1990). The formal legal institutions include rules and regulations; informal institutions include norms, culture and ethics (Scott, 1995). As rules, norms and morals vary by country, MNEs bear additional costs in searching for information and resources, including getting acquainted with the managerial practices of the local labor market and laws and 
hiring local lawyers and agencies, in order to gain legitimacy and acceptance in the host countries (DiMaggio \& Powell, 1983; Eden \& Miller, 2001).

Due to their lack of legitimacy in the host country, foreign firms are more likely to experience adverse treatment by local stakeholders, such as governments, customers and suppliers (Denk et al., 2012; Newburry, Gardberg, \& Belkin, 2006). Aside from discriminatory attitudes towards foreign firms due to political pressure or a hostile relationship between home and host countries (Henisz \& Williamson, 1999), local regulatory agencies often consider national security issues when ratifying a deal (Li et al., 2017). Consumer ethnocentrism towards foreign brands also adds extra costs to MNCs (Balabanis, Diamantopoulos, Mueller, \& Melewar, 2001). It also takes foreign firms time and effort to build their business networks with local suppliers and distributors, due to their lack of embeddedness and trust (Cuervo-Cazurra, Maloney, \& Manrakhan, 2007; Eden \& Miller, 2004).

On the one hand, high-quality legal systems can reduce the uncertainty in transactions and promote inward FDI. With stable and well-designed rules of law, enterprises would have more complete and accurate transactions in the market so as to facilitate MNEs' preliminary investigations (Muehlfeld, Sahib, \& Van Witteloostuijn, 2007; North, 1990). As foreign companies have more difficulties in undertaking and learning the legalities than domestic companies, if the law is clear and systematic it will reduce the foreign enterprises' cost of learning; in contrast, if the law is ambiguous, foreign enterprises have to expend high costs to learn the local hidden rules and practices.

On the other hand, the complexity of legal and institutional systems also provides an excuse for investment protectionism. The initial intention is quite plausible; for instance, the American federal anti-trust law regulates that if an M\&A deal jeopardizes competition or leads to monopoly, then it will be disapproved (Wier, 1983). Yet the acquisition regulations may aim to protect "national security" through vague criteria that leave regulatory agencies a great deal of discretion (Li et al., 2017). The US has several laws concerning the security review of foreign capital, such as the Exxon-Florio Action, involving national security review of foreign mergers and acquisitions, and the Foreign Investment and National Security Act in which the security review is expanded from national security to economic security. In Canada, the Foreign Investment Review Act and Investment Canada Act have established holistic review procedures to ensure Canada can gain "net benefit” from inward FDI. Similar laws are very common; there are around 90 similar laws world-wide (Singh, 2002). In most cases, the foreign acquirer must notify the government or even gain approval before the investment takes place. There are around 90 countries world-wide that require diligent examination of every publicly announced M\&A deal to assess the possibility of it creating a monopoly (Singh, 2002).

It follows that investment protection activities will arise during the scrupulous case-by-case examination process and that host countries where institutions are more mature and well-run will have more excuses to cover the purpose of protectionism. Some scholars have even found that Chinese MNEs prefer to invest in destinations with low-quality or high-risk institutions, dubbed the "risk paradox" (Kolstad \& Wiig, 2012). Thus, we propose:

H1b: The quality of a host country's institutional system serves as a double-edged sword that can influence the realization of MNEs' CBMA intentions in either direction.

\subsection{The Moderating Role of Firms' Identity}

Since China has arisen as an important player in the world economy, Chinese enterprises investing overseas have been met with skeptical and cautious attitudes from the international community under the rampant fear of the "China threat". The hostility caused by identity is manifested in three aspects:

Chinese state-owned enterprises' CBMA activities are perceived as having dual motivations. There is an obvious "non-market motivation" besides profit orientation (Morck et al., 2008). Host governments and public opinion have difficulty accepting bidders that receive subsidies from their government and operate with "political intentions" (Cuervo-Cazurra, Inkpen, \& Musacchio, 2014; Wan \& Wong, 2009). Moreover, opaque management practices that suppress the disclosure of information will reinforce the above concerns and present state-owned 
firms with additional challenges (Li et al., 2017). These concerns contribute to the labeling of the state-owned enterprises' identity and causes discrimination against these enterprises on the part of the host government and/or the public (Zhang, Zhou, \& Ebbers, 2011). The identity of "state-owned", which may be advantageous in their home country, could be a burden to enterprises in the host countries.

Industry features have a direct influence on firms' strategy (Porter, 1980). As more and more MNEs speed up their expansions in key industries, host countries have come to realize the significance of energy resources and advanced technologies in securing the development of their economy and social stability; as a result, these factors have been integrated into the category of national security system and are supervised strictly. The Foreigners Acquisitions and Takeovers Act in Australia requires project application and approval of foreign acquisitions in key areas such as mining, finance and media. The Foreign Investment and National Security Act of the US government stipulates that if a Foreign M\&A threatens the leadership in key technology areas, influences local employment or leads to bypassing the export control of the US's core technologies, it will be regarded as a threat to national security, and the President will be empowered to suspend or terminate the transaction. Thus, we propose:

H2a: When the acquirer is a state-owned enterprise, the negative effects of LOF will be magnified.

Hob: When the deal concerns the technology industry, the negative effects of LOF will be magnified.

Hoc: When the deal concerns the energy industry, the negative effects of LOF will be magnified.

\subsection{The Role of Experience}

MNEs experience LOF mainly because of the information asymmetry and the lack of legitimacy caused by formal and informal institutions. The tacit attributes of the complicated written procedures, as well as the informal and unwritten norms and practices, are more difficult for foreign firms to learn and understand compared to indigenous firms (Calhoun, 2002). However, a firm's accumulated experience will bring more additional benefits, e.g. awareness of financial options, the collection of important industry information, the establishment of business networks and relationship capital, the identification of the right acquisition targets, increased skill in communications and negotiations with local stakeholders, or even greater understanding of the hidden rules of the local informal institutions (Beckman \& Haunschild, 2002; Delios \& Beamish, 2001; Li et al., 2017). Through practical experience, it is much easier for firms to get acquainted, comprehend or even become isomorphic within international settings, thereby mitigating LOF in subsequent M\&A transactions (Sethi \& Guisinger, 2002).

In spite of the above general knowledge on how experience can help mitigate LOF, theory and literature suggest that learning is highly context specific, especially when it concerns the relatively rare, complex and heterogeneous corporate activities of CBMA (Haleblian \& Finkelstein, 1999; Zollo, 2009). Prior experience does not necessarily lead to gains in knowledge or skills to successfully tackle the complexity of a subsequent CBMA project. It is more likely that experience play a greater role in institutionally less distant countries (Dikova et al., 2010). Variation of context may cause firms to draw incorrect inferences, which substantially hinders the effectiveness of learning (Haleblian \& Finkelstein, 1999; Muehlfeld, Rao Sahib, \& Van Witteloostuijn, 2012). Inspired by prior research (Johanson \& Vahlne, 1977; Kostova \& Zaheer, 1999) that recommends MNEs enter institutionally similar blocs to their home country to reduce the negative effects of LOF, we argue that prior experience in a similar context can also be effective in combating LOF.

We classify experience according to the relatedness of context and content. Context-related experience is categorized based on the similarity of the environment to one that the MNC has operated in before. A high level of context-related experience is gained by operating in the local environment or an institutionally similar environment, where market-specific knowledge is acquired, such as customs, culture, laws and other regulations. Market-specific knowledge can help companies identify the differences between home and host business settings, adopt routine practices to fit the host institutional environment, and negotiate with the host country stakeholders, which can effectively mitigate LOF caused by information asymmetry (Dikova et al., 2010; Kostova \& Zaheer, 
1999). Low context-related experience means that the MNE's past operational experience was in institutionally distant international markets. Learning in largely different environments around the world exposes firms to different events and ideas, hence they will be more likely to develop an extensive knowledge base (Hedberg, 1981). Organizations with a higher learning capability can utilize opportunities to avoid the managerial inertia that results in repetitive business settings (Abrahamson \& Fombrun, 1994; Fiol \& Lyles, 1985; Levitt \& March, 1988). In the long run, enterprises that deal with limited competitors and customers increase their investment risk due to the lack of learning opportunities (Hayward, 2002). However, given the immaturity of EMNCs, we posit they are more likely to fit in the high-context-related environment.

Content-related experience refers to prior operations that had the same patterns of FDI. Firms can choose either M\&A or green-field investment when entering enter host countries. However, different types of knowledge are involved in different pattern choices. The M\&A pattern requires more knowledge and skills in negotiating with the target firm and stakeholders, such as due diligence, gaining legitimacy with stakeholders, circumventing antitrust regulations, and negotiating the deal price and rearrangement of incumbent management teams and employees, during which process firms need to rely on the aid of local external consultants (Very \& Schweiger, 2001). On the other hand, green-field investment mainly deals with location choice factors, such as market size, distance and availability of labor resources and suppliers. In this sense, prior CBMA activity is considered highcontent-related experience that can contribute relevant knowledge to the focal acquisition, and green-field investment experience is considered low-content-related experience. However, prior experience of green-field investment in an environmentally similar market may still be helpful in combating LOF, for it can provide contextual knowledge and skills as discussed above.

Hence, we developed a matrix to help categorize the degree of international experience based on the two dimensions of relatedness: context and content. As shown in Figure 1, prior CBMA experience in the same or institutionally similar host countries is considered both high-context and high-content experience, which is the most favorable type of experience; prior CBMA experience in institutionally distant host countries is considered low-context and high-content experience. Prior green-field investment experience in the same or institutionally similar host countries is considered high-context and low-content experience, and prior green-field investment experience in institutionally distant host countries is low-context and low-content experience. Thus, we propose

H3: LOF exerts fewer adverse effects on EMNCs with prior outward FDI experience in their realization of CBMA intentions, depending on the degree of context/content relatedness of the experience

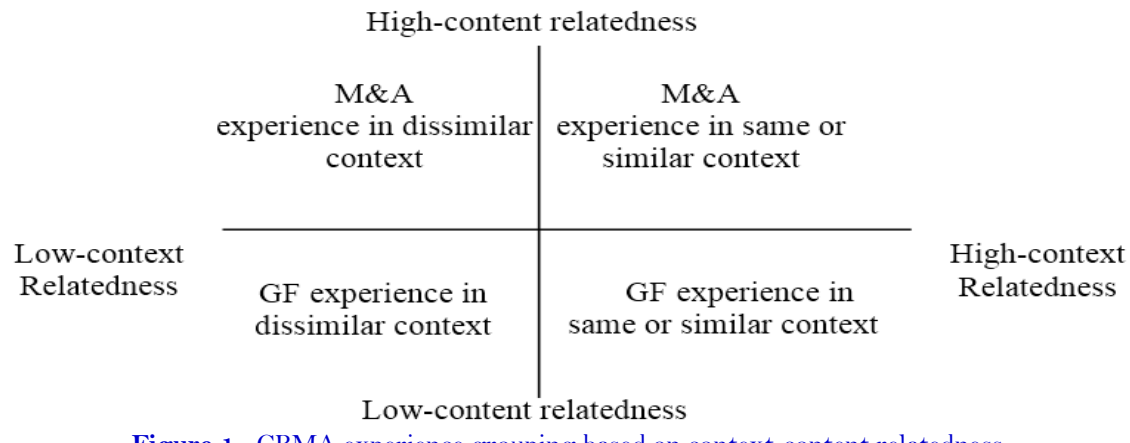

Note: GF: green field investment.

\section{THE MODEL AND DATA}

\subsection{Model Design}

The outcomes of the 574 transactions of Chinese enterprises' overseas acquisitions between 2005 and 2014 are taken as the dependent variable, which is a dummy variable. A successful case is valued as 1 , and o otherwise. A probit model is used to test the hypotheses using Stata15.0 software. 
Model 1 \& Model 2 explore the driving forces of LOF at the pre-CBMA stage; Model 3 through Model 5 identify the moderating effects from the static perspective, i.e., how organizational identity affects the degree of LOF; Model 6 through Model 11 investigate the moderating effects from the dynamic perspective, i.e., the role of accumulated context/content experience on the degree of LOF.

We use sub-samples to study the moderating effects of experience for the following reason: the data shows that two dimensions (culture and law quality) that measure the relatedness of contextual experience correlate highly (0.8) with each other, i.e., culturally adjacent countries are likely to also have less regulatory distance. Given this connection, we cannot simply use cultural contextual experience to moderate the "cultural distance" variable, and regulatory contextual experience to moderate the "law quality" variable, due to the high correlation of the moderators and the subsequent difficulty in interpreting the results. Therefore, we use different sub-groups to investigate the role of contextual/content experience and their moderating effects on the driving forces of LOF.

\subsection{Sample}

The data in this study is taken from the regularly published "China Global Investment Tracking" (CGIT) reports from the Heritage Fund, which aim to track Chinese investment cases. The database supplied by the report covers more than 1,100 transactions, including 599 investment and 441 construction contracts during the period 2005-2014. The reports confirmed 130 projects as "problematic transactions", meaning that they were rejected by the host country authorities, suffered huge property damage, or failed because of investors' mistakes. This paper incorporates both the successful and failed cases, and thus involves $729 \mathrm{M} \& \mathrm{~A}$ transactions, excluding the construction contracts. The software automatically identified 574 samples, and the remainder are due to incomplete data that failed to be matched by the statistical software. The descriptions of all the variables and data sources can be found in Table 1, and the overall statistical descriptions and correlation matrix are shown in Table 2 and Table 3 respectively. From the results of the VIF test in Table 4, it can be seen that the VIF values of all variables are below the threshold of 10 , indicating that there is no significant multicollinearity in the models.

\subsection{Variables}

\subsubsection{Dependent Variable}

In this paper, the 574 outcomes of the Chinese overseas M\&A transactions are treated as the dependent variable. This is a dummy variable, with successful cases valued 1, and failed cases valued o.

\subsection{The Independent Variables}

Hofstede developed the cultural dimension theory to define the distinctiveness of cultures across countries, i.e., in terms of individualism-collectivism, power distance, uncertainty avoidance, masculinity-femininity, long-term or short-term orientation. In our study, culture is measured in these five dimensions and the following formula is adopted to calculate the cultural distance, consistent with the prior research of Kogut and Singh (1988).

$$
\mathrm{CD}_{\mathrm{j}}=\sum_{i=1}^{5}\left\{\left(I_{i j}-I_{i c}\right)^{2} / V_{i}\right\} / 5
$$

$C D_{j}$ represents the cultural distance between China and country j。 $I_{i j}$ stands for the index of the $i$ th cultural dimension of country j, while $I_{i j}$ is the Chinese index on $i$ th cultural dimension. $V_{i}$ is the variance of the $i$ th dimension vector. The data on each country's cultural dimensions is extracted from Hofstede's website on culture (http://www.geerthofstede.com/).

We combine "rule of law" and "regulatory quality" governance from WGI into a single index by averaging the two indicators, which is used as a proxy to represent the quality of the formal institutions of laws and regulations. 
Asian Development Policy Review, 2022, 10(1): 16-34

Table 1. Definitions and sources of variables.

\begin{tabular}{|c|c|c|c|}
\hline Variables & Full name & Definition and measurements & Sources \\
\hline cul_dis & $\begin{array}{l}\text { cultural } \\
\text { distance }\end{array}$ & $\begin{array}{l}\text { Cultural distance between China and other } \\
\text { countries }\end{array}$ & $\begin{array}{l}\text { Kogut and Singh's (1988) } \\
\text { formula using data extracted } \\
\text { from Hofstede's website }\end{array}$ \\
\hline law quality & $\begin{array}{l}\text { quality formal } \\
\text { institutions }\end{array}$ & $\begin{array}{l}\text { Quality of host country formal institutions } \\
\text { measured by "rule of law" and "regulatory quality" }\end{array}$ & World Governance Indicator \\
\hline law_dis & $\begin{array}{l}\text { formal } \\
\text { institutions } \\
\text { distances }\end{array}$ & $\begin{array}{l}\text { The distances between host country formal } \\
\text { institutions and China's }\end{array}$ & $\begin{array}{l}\text { Calculated from World } \\
\text { Governance Indicator }\end{array}$ \\
\hline freedom & $\begin{array}{l}\text { economic } \\
\text { freedom }\end{array}$ & Index of Economic Freedom & The Heritage Foundation \\
\hline gov_stability & $\begin{array}{l}\text { government } \\
\text { stability }\end{array}$ & $\begin{array}{l}\text { Political Stability measured by "Absence of } \\
\text { Violence" }\end{array}$ & World Governance Indicator \\
\hline lnquantity & $\begin{array}{l}\text { the } \\
\text { transaction } \\
\text { amount }\end{array}$ & Logarithm of the total amount of transactions & $\begin{array}{l}\text { China Global Investment } \\
\text { Tracking database }\end{array}$ \\
\hline $\operatorname{lnsize}$ & $\begin{array}{l}\text { size of the } \\
\text { acquirer }\end{array}$ & Size of the acquirer measured by sales & Firms' annual reports \\
\hline central & $\begin{array}{l}\text { state-owned } \\
\text { enterprises }\end{array}$ & $\begin{array}{l}\text { Dummy variable. } 1 \text { represents the acquirer being a } \\
\text { state-owned enterprise, and o otherwise }\end{array}$ & $\begin{array}{l}\text { State-owned assets } \\
\text { supervision and } \\
\text { administration commission of } \\
\text { the state council }\end{array}$ \\
\hline sec_energy & $\begin{array}{l}\text { energy } \\
\text { industry }\end{array}$ & $\begin{array}{l}\text { Dummy variable. } 1 \text { represents energy industry } \\
\text { acquisition, and o otherwise }\end{array}$ & $\begin{array}{l}\text { China Global Investment } \\
\text { Tracking database }\end{array}$ \\
\hline sec_tech & $\begin{array}{l}\text { high- } \\
\text { technology } \\
\text { industry }\end{array}$ & $\begin{array}{l}\text { Dummy variable. } 1 \text { represents high-technology } \\
\text { industry acquisition, and o otherwise }\end{array}$ & $\begin{array}{l}\text { China Global Investment } \\
\text { Tracking database }\end{array}$ \\
\hline $\begin{array}{l}\text { Context- } \\
\text { related } \\
\text { experience }\end{array}$ & & $\begin{array}{l}\text { Dummy variable. } 1 \text { represents high-context } \\
\text { experience, meaning the firm has previously } \\
\text { operated in a host country that has lower cultural } \\
\text { and regulatory distances. Failure to meet this } \\
\text { criterion is classified as low-context related } \\
\text { experience and coded as o }\end{array}$ & $\begin{array}{l}\text { M\&A experience extracted } \\
\text { from China Global } \\
\text { Investment Tracking } \\
\text { database; Green field } \\
\text { experience from FDI market. }\end{array}$ \\
\hline $\begin{array}{l}\text { Content- } \\
\text { related } \\
\text { experience }\end{array}$ & & $\begin{array}{l}\text { Dummy variable. } 1 \text { represents high-content } \\
\text { experience, which is } \mathrm{M} \& \mathrm{~A} \text { experience; } \mathrm{O} \\
\text { represents low-content experience, which is green } \\
\text { field experience }\end{array}$ & $\begin{array}{l}\text { M\&A experience extracted } \\
\text { from China Global } \\
\text { Investment Tracking } \\
\text { database; Green field } \\
\text { experience from FDI market. }\end{array}$ \\
\hline
\end{tabular}

Table 2. Statistical description of variables.

\begin{tabular}{l|c|c|c|c|c|c}
\hline Var Name & Obs & Mean & SD & Min & Median & Max \\
\hline victory & 602 & 0.83 & 0.37 & 0.00 & 1.00 & 1.00 \\
\hline cul_dis & 602 & 3.26 & 1.58 & 0.57 & 3.34 & 7.82 \\
\hline Law quality & 602 & 0.72 & 0.20 & 0.17 & 0.83 & 1.00 \\
\hline law_dis & 602 & 0.24 & 0.12 & 0.01 & 0.28 & 0.45 \\
\hline freedom & 602 & 67.77 & 13.01 & 22.10 & 69.10 & 88.40 \\
\hline gov_stability & 602 & 0.72 & 0.08 & 0.42 & 0.73 & 0.91 \\
\hline lnquantity & 602 & 6.25 & 1.14 & 4.61 & 6.16 & 9.88 \\
\hline lnsize & 602 & 10.65 & 2.46 & 2.94 & 10.82 & 15.08 \\
\hline central & 602 & 0.59 & 0.49 & 0.00 & 1.00 & 1.00 \\
\hline sect_tech & 602 & 0.16 & 0.37 & 0.00 & 0.00 & 1.00 \\
\hline sect_energy & 602 & 0.52 & 0.50 & 0.00 & 1.00 & 1.00 \\
\hline m\&a experience & 601 & 0.29 & 0.45 & 0.00 & 0.00 & 1.00 \\
\hline green field experience(gf) & 602 & 0.02 & 0.16 & 0.00 & 0.00 & 1.00 \\
\hline high-cultural-context m\&a experience & 602 & 0.57 & 0.50 & 0.00 & 1.00 & 1.00 \\
\hline high-law-context m\&a experience & 602 & 0.57 & 0.50 & 0.00 & 1.00 & 1.00 \\
\hline high-cultural-context gf experience & 602 & 0.23 & 0.42 & 0.00 & 0.00 & 1.00 \\
\hline high-law-context gf experience & 602 & 0.22 & 0.41 & 0.00 & 0.00 & 1.00 \\
\hline
\end{tabular}


Table 3. Correlation matrix.

\begin{tabular}{|c|c|c|c|c|c|c|c|c|c|c|c|c|c|c|c|c|c|c|}
\hline & 1 & 2 & 3 & 4 & 5 & 6 & 7 & 8 & 9 & 10 & 11 & 12 & 13 & 14 & 15 & 16 & 17 & 18 \\
\hline \multicolumn{19}{|l|}{ 1.victory } \\
\hline 2.culdis & $-0.11^{*}$ & & & & & & & & & & & & & & & & & \\
\hline 3.law quality & 0.01 & $0.14 *$ & & & & & & & & & & & & & & & & \\
\hline 4.lawdis & 0.02 & $0.26^{*}$ & $0.70^{*}$ & & & & & & & & & & & & & & & \\
\hline 5.freedom & $0.11^{*}$ & $0.12^{*}$ & $0.72^{*}$ & $0.71^{*}$ & & & & & & & & & & & & & & \\
\hline 6.gov_stability & -0.02 & $0.11^{*}$ & 0.39* & $0.45^{*}$ & $0.42 *$ & & & & & & & & & & & & & \\
\hline 7.lnquantity & $-0.24^{*}$ & 0.05 & -0.03 & -0.01 & -0.08 & -0.02 & & & & & & & & & & & & \\
\hline 8.lnsize & -0.06 & -0.07 & -0.07 & -0.04 & $-0.13^{*}$ & -0.04 & $0.22^{*}$ & & & & & & & & & & & \\
\hline 9.sect_related & $-0.09^{*}$ & 0.06 & $-0.10^{*}$ & -0.03 & -0.06 & -0.02 & $0.11^{*}$ & 0.09* & & & & & & & & & & \\
\hline 10.central & $-0.09^{*}$ & -0.04 & $-0.10^{*}$ & -0.05 & $-0.11^{*}$ & -0.01 & $0.31 *$ & $0.37 *$ & $0.11^{*}$ & & & & & & & & & \\
\hline 11.sect_tech & -0.04 & -0.03 & 0.06 & 0.06 & $0.13^{*}$ & -0.01 & -0.05 & 0.01 & $0.14^{*}$ & 0.00 & & & & & & & & \\
\hline 12.sect_energy & -0.02 & 0.02 & $-0.11 *$ & -0.07 & $-0.12^{*}$ & -0.05 & $0.22 *$ & $0.09 *$ & $0.22^{*}$ & $0.30^{*}$ & $-0.46^{*}$ & & & & & & & \\
\hline 13.exp1 & $-0.11^{*}$ & 0.06 & $0.14^{*}$ & $0.13^{*}$ & $0.16^{*}$ & -0.01 & $0.20^{*}$ & $0.16^{*}$ & 0.03 & $0.25^{*}$ & $0.10^{*}$ & 0.07 & & & & & & \\
\hline 14.exp2 & 0.01 & $-0.16^{*}$ & $-0.17 *$ & $-0.12^{*}$ & $-0.14^{*}$ & $-0.14^{*}$ & -0.02 & 0.03 & 0.05 & 0.00 & -0.01 & 0.05 & -0.01 & & & & & \\
\hline $15 . \exp 3$ & -0.06 & $-0.11^{*}$ & 0.04 & 0.01 & -0.01 & -0.06 & $0.22^{*}$ & $0.38^{*}$ & 0.04 & $0.37 *$ & $0.11^{*}$ & $0.10^{*}$ & $0.41 *$ & 0.01 & & & & \\
\hline 16.exp4 & $-0.09 *$ & -0.01 & 0.04 & -0.01 & -0.02 & -0.07 & $0.24 *$ & $0.36^{*}$ & 0.03 & $0.33^{*}$ & $0.09^{*}$ & $0.09^{*}$ & $0.41^{*}$ & 0.01 & $0.79^{*}$ & & & \\
\hline 17.exp5 & 0.04 & $-0.20^{*}$ & $-0.17^{*}$ & $-0.09 *$ & $-0.16^{*}$ & $-0.12^{*}$ & 0.01 & $0.29^{*}$ & 0.09* & $0.14^{*}$ & -0.02 & $0.09^{*}$ & 0.07 & $0.30^{*}$ & $0.16^{*}$ & $0.12^{*}$ & & \\
\hline $18 . \exp 4$ & -0.06 & $-0.11 *$ & $-0.14^{*}$ & $-0.19^{*}$ & $-0.14^{*}$ & -0.06 & 0.01 & $0.19^{*}$ & 0.03 & 0.06 & 0.07 & 0.02 & 0.01 & $0.30^{*}$ & $0.12^{*}$ & $0.12^{*}$ & $0.28^{*}$ & \\
\hline
\end{tabular}

Note:

Lower-triangular cells report Pearson's correlation coefficients, upper-triangular cells are Spearman's rank correlation * $p<0.05$

exp3:high-cultural-context m\&a experience

exp4: high-law-context m\&a experience;

exp5: high-cultural-context gf experience

exp6: high-law-context gf experience. 
Asian Development Policy Review, 2022, 10(1): 16-34

Table 4. The result of VIF test (reporting only the highest five variables

\begin{tabular}{l|c|c}
\hline Variable & VIF & 1/VIF \\
\hline freedom & 3 & 0.333633 \\
\hline cultext & 2.92 & 0.34259 \\
\hline lawtext & 2.78 & 0.360208 \\
\hline law & 2.75 & 0.36354 \\
\hline lawdis & 2.67 & 0.374388 \\
\hline Mean VIF & 1.77 & \\
\hline
\end{tabular}

3.5. Moderating Variables

3.5.1. Organizational Characteristics

$S O E$ identity is based on the records of the State-owned assets supervision and administration commission of the state council. Sensitive sector of either technology or energy is the original classification in the China Global Investment Tracking database.

\subsubsection{Contextual and Content Related Experience}

We investigate the degree of relatedness between the focal country and prior host country indirectly by using China as benchmark, because of the lack of available data. If the difference between the two countries' cultural distance is lower than the standard deviation of the culture distance variable, we regard the prior experience as highly related cultural context and take the value as 1, and o otherwise. In terms of the relatedness of the formal institutions of laws and regulations, we calculate the distance between the focal host country and prior host country directly by means of their own index, comparing each to the standard deviation of the "law quality" variable. We regard the prior experience as highly related law context and take the value as 1, and o otherwise. We define prior FDI experience in both culturally and regulatory adjacent countries (both cultural and law context are rated as 1) as highly related contextual experience, while failing to meet these criteria, i.e., experience in either culturally or regulatorily distant countries, or a complete lack of prior experience, is categorized as low related contextual experience. The calculation is made twice for both the prior M\&A and green field dataset respectively. And hence we arrive at four sets of categories, i.e., highly-related context M\&A experience, low-related context M\&A experience, highly-related context GF experience and low-related context GF experience.

\subsection{Control Variables}

Economic freedom: The high quality of an economic system is reflected in the free flow of capital, goods and labor, and no limitation on individuals to pursue and sustain economic independence Beach and Kane (2008). The higher the quality of the economic system, the lower the degree of government intervention in the economy. The degree of government interference or economic freedom can influence the realization of MNEs' CBMA intentions.

Political environment: The volatility of the political environment in a host country increases the uncertainty of multinational investment, where the political risks include civil armed conflict, political strikes, riots, terrorism and external conflicts. Dixit and Pindyck (1994) highlight the impact of uncertainty on investment decisions. For the irreversible FDI, when the benefits and costs associated with political uncertainty are yet unknown, the investors may take a "wait and see" approach to their investment. As the political risk is applied equally to domestic and foreign enterprises, and the extra management cost is not solely borne by foreign enterprises, it is not included in LOF, so is treated as a control variable in this paper.

Scale of transaction: Large M\&A deals may arouse increased scrutiny by stakeholders such as host country governments and major competitors in the same industry and, as a result, may lead to failure of the deal.

Size of the firm: The firm's size is controlled for to reflect the heterogenicity of each CBMA case.

\section{RESULTS}

Table 5 shows the results of the sources of LOF as well as the moderating effects of organizational identity on the completion of CBMA. Model o includes control variables only, as a benchmark specification. Based on Model o, 
the independent variables cultural difference and law quality are included in Model 1. In Model 2, we replaced law quality with law quality distance for the purpose of comparison, thus justifying our standpoint on the drivers of LOF from a formal institution perspective. We next add firm attributes that are more likely to arouse regulatory concerns into the model as moderating factors of formal institutions, for which reason SOE identity, technological sector and energy sector are added respectively in Models 3, 4 and 5.

Table 6 shows the degree of LOF exposure contingent on the different degrees of context/content related experience of EMNCs. Models 6-11 are listed from the highest level of experience relatedness to the lowest level of relatedness. Model 6 is composed of firms with prior M\&A experience in the host country. We include firms that have either M\&A experience or GF experience in Model 7, because the number of firms with prior host-country GF experience is very limited (only 8 cases), such that it is not feasible to reach a regression result for these as a subgroup alone. Model 8 is the subgroup of firms with high-related contextual experience in M\&A (high-content related). And Model 9 concerns firms with either high-related M\&A or GF experience, for the same reason as in Model 7. Model 8 represents the subgroup of firms with low-contextual and high-content (M\&A) experience, and Model 9 is firms with low-contextual and low-content (GF) experience.

For each model, we report the coefficients, $t$ statistics, the value of the likelihood function at convergence, chisquare statistics and pseudo R-square. The chi-square statistics are significant at the $1 \%$ level, signifying that the null hypothesis is rejected and hence a good model fit for all models. The coefficients of cultural distance and law quality are both negatively significant $(\mathrm{p}<0.05)$, supporting $\mathrm{H} 1 \mathrm{a}$ and $\mathrm{H} 1 \mathrm{~b}$. This indicates that the greater the cultural difference, the more likely it is that bidding for M\&A cases fails, and higher degrees of complication of the host-country law systems have the same effect. In Model 2, we replace the variable law quality from Model 1 with law distance, the effects of which fails to be significant, and the pseudo R-square of Model 2 is also lower than that of Model 1. The results of the moderating effects in Model 3, Model 4 and Model 5 show that technological sector has a negative and significant $(\mathrm{p}<0.05)$ marginal effect of LOF on the completion likelihood of CBMA, consistent with H2b. However, SOE identity and energy sector fail to show any significant marginal effect, and thus H2a and H2c are not supported.

Table 6 reports the results of the degree that LOF effects are contingent on different shades of outward FDI experience. Interestingly, if the firm has prior experience operating in an exact or highly related institutional context (Model 7, Model 9 and Model 10), the cultural distance ceases to exert significant adverse effects on the completion of CBMAs, however, the quality of laws still has a significantly negative effect on CBMA completion. In Model 8, when adding local GF investment to Model 7, law quality becomes insignificant, suggesting experience from local GF investment does have a positive role in reducing regulatory barriers. Model 11 is exactly the opposite sample of that in Model 9, and the results of cultural distance and law quality display the opposite significance. In other words, when prior highly related contextual experience is 0 , cultural distance has a negative impact on the completion of CBMA; however, if prior highly related contextual experience is 1, the marginal effect of cultural distance is no longer significant, indicating that highly related experience reduces the negative impact of cultural distance. On the contrary, when prior highly related contextual experience is o, law quality has an insignificant effect, however, if highly related contextual experience is 1, the marginal impact of law quality is negatively significant, indicating that highly related experience decreases the negative impact of law quality. Finally, the results in Model 12 suggest having low levels of related context/content experience fails to reduce the drivers of LOF, as expected. Hence, H3 is partly supported. In addition, as is shown in Table 7, we have looked at the results of Logit regression on the robustness check of the law quality variable, and the results are consistent with the main regression results, implying that our results are robust and consistent. 
Asian Development Policy Review, 2022, 10(1): 16-34

Table 5. The results of LOF factors influencing the completion of CBMAs.

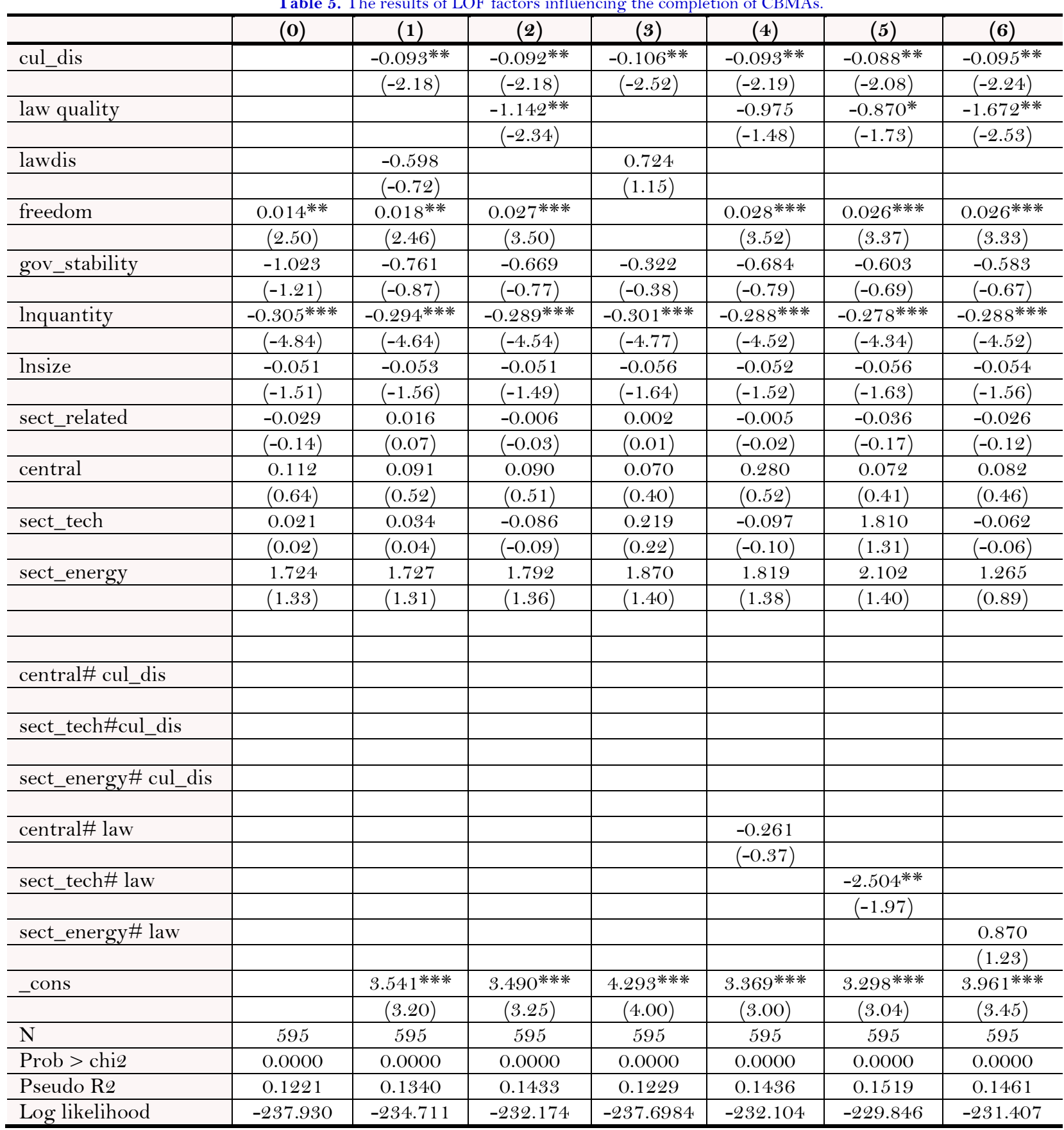

Note: ${ }^{*} \mathrm{p}<0.1 ; * * \mathrm{p}<0.05 ; * * * \mathrm{p}<0.01$ 
Asian Development Policy Review, 2022, 10(1): 16-34

Table 6. The regression results based on groups with different degrees of internationalization experience.

\begin{tabular}{|c|c|c|c|c|c|c|}
\hline & $(7)$ & $(8)$ & $(9)$ & $(10)$ & $(11)$ & $(12)$ \\
\hline & $\begin{array}{c}\text { Same contextual } \\
\text { M\&A exp }\end{array}$ & $\begin{array}{l}\text { Same contextual } \\
\text { M\&A or GF exp }\end{array}$ & $\begin{array}{c}\text { High-related } \\
\text { contextual M\&A exp }\end{array}$ & $\begin{array}{c}\text { High-related contextual } \\
\text { M\&A or GF exp }\end{array}$ & $\begin{array}{c}\text { Low-related } \\
\text { contextual M\&A exp }\end{array}$ & $\begin{array}{c}\text { Low-related } \\
\text { contextual GF exp }\end{array}$ \\
\hline \multirow[t]{2}{*}{ cul_dis } & -0.034 & -0.047 & -0.093 & -0.060 & $-0.184^{* * *}$ & $-0.089^{*}$ \\
\hline & $(-0.22)$ & $(-0.34)$ & $(-1.28)$ & $(-0.86)$ & $(-2.36)$ & $(-1.76)$ \\
\hline \multirow[t]{2}{*}{ law quality } & $-2.248^{*}$ & -1.414 & $-1.882^{* *}$ & $-1.539 * *$ & -0.560 & $-1.569^{* *}$ \\
\hline & $(-1.75)$ & $(-1.18)$ & $(-2.35)$ & $(-2.07)$ & $(-0.49)$ & $(-2.36)$ \\
\hline \multirow[t]{2}{*}{ freedom } & 0.023 & 0.013 & $0.033^{* * *}$ & $0.032 * * *$ & $0.031^{*}$ & $0.033^{*} * *$ \\
\hline & $(1.15)$ & $(0.66)$ & $(2.81)$ & $(2.78)$ & $(1.66)$ & $(3.29)$ \\
\hline \multirow[t]{2}{*}{ gov_stability } & 1.935 & 1.708 & -1.768 & -1.917 & -0.678 & 0.082 \\
\hline & $(0.93)$ & $(0.84)$ & $(-1.41)$ & $(-1.57)$ & $(-0.36)$ & $(0.07)$ \\
\hline \multirow[t]{2}{*}{ Inquantity } & $-0.239 *$ & $-0.226^{*}$ & $-0.274 * * *$ & $-0.275 * * *$ & $-0.370^{* * *}$ & $-0.271 * * *$ \\
\hline & $(-1.90)$ & $(-1.93)$ & $(-3.05)$ & $(-3.25)$ & $(-2.52)$ & $(-3.39)$ \\
\hline \multirow[t]{2}{*}{ Insize } & $-0.288 * * *$ & $-0.277^{*} * *$ & -0.072 & -0.068 & -0.034 & $-0.087^{*}$ \\
\hline & $(-3.16)$ & $(-3.26)$ & $(-1.35)$ & $(-1.37)$ & $(-0.46)$ & $(-1.83)$ \\
\hline \multirow[t]{2}{*}{ sect_related } & 0.128 & 0.100 & -0.155 & -0.166 & 0.479 & 0.125 \\
\hline & $(0.18)$ & $(0.14)$ & $(-0.47)$ & $(-0.52)$ & $(0.94)$ & $(0.49)$ \\
\hline \multirow[t]{2}{*}{ central } & $1.150^{* *}$ & $1.031^{* *}$ & 0.262 & 0.284 & 0.411 & -0.003 \\
\hline & $(2.51)$ & $(2.30)$ & $(0.83)$ & $(0.95)$ & $(1.12)$ & $(-0.01)$ \\
\hline \multirow[t]{2}{*}{ sect_tech } & 1.205 & 1.274 & 2.743 & 2.696 & 4.120 & -0.083 \\
\hline & $(1.34)$ & $(1.42)$ & $(0.01)$ & $(0.01)$ & $(0.01)$ & $(-0.07)$ \\
\hline \multirow[t]{2}{*}{ sect_energy } & $4.271 * *$ & $4.130^{* * *}$ & 9.243 & 9.420 & $0.881^{*}$ & 2.387 \\
\hline & $(2.40)$ & $(2.46)$ & $(0.03)$ & $(0.02)$ & $(1.94)$ & $(1.57)$ \\
\hline \multirow[t]{2}{*}{ _cons } & $3.745^{*}$ & $3.934 * *$ & $4.154 * * *$ & $2.753^{*}$ & 2.451 & $2.377^{*}$ \\
\hline & $(1.91)$ & $(2.16)$ & $(3.17)$ & $(1.82)$ & $(1.38)$ & $(1.75)$ \\
\hline $\mathrm{N}$ & 143 & 151 & 307 & 334 & 152 & 388 \\
\hline Prob > chi2 & 0.0000 & 0.0000 & 0.0000 & 0.0000 & 0.0000 & 0.0000 \\
\hline Pseudo R2 & 0.2554 & 0.2326 & 0.1790 & 0.1848 & 0.2568 & 0.1870 \\
\hline Log likelihood & -61.644 & -66.993 & -122.159 & -131.837 & -53.965 & -139.927 \\
\hline
\end{tabular}


Table 7. Results of Logit regression on Robustness check of law quality variable.

\begin{tabular}{|c|c|c|c|}
\hline & (13) & $(14)$ & $(15)$ \\
\hline & victory & victory & victory \\
\hline \multirow[t]{2}{*}{ culdis } & $-0.165^{* *}$ & $-0.169^{* *}$ & $-0.192^{* * *} *$ \\
\hline & $(-2.18)$ & $(-2.24)$ & $(-2.58)$ \\
\hline \multirow[t]{2}{*}{ law quality } & $-2.259 * *$ & & \\
\hline & $(-2.54)$ & & \\
\hline \multirow[t]{2}{*}{ lawdis } & & -0.967 & 1.273 \\
\hline & & $(-0.65)$ & $(1.13)$ \\
\hline \multirow[t]{2}{*}{ freedom } & $0.049 * * *$ & $0.030^{* * *}$ & \\
\hline & $(3.57)$ & $(2.34)$ & \\
\hline \multirow{2}{*}{ gov_stability } & -1.104 & -1.417 & -0.714 \\
\hline & $(-0.70)$ & $(-0.88)$ & $(-0.45)$ \\
\hline \multirow[t]{2}{*}{ lnquantity } & $-0.523 * * *$ & $-0.527 * * *$ & $-0.534^{* * * *}$ \\
\hline & $(-4.59)$ & $(-4.65)$ & $(-4.75)$ \\
\hline \multirow[t]{2}{*}{ lnsize } & -0.100 & -0.099 & $-0.107^{*}$ \\
\hline & $(-1.61)$ & $(-1.61)$ & $(-1.76)$ \\
\hline \multirow[t]{2}{*}{ sect_related } & -0.111 & -0.040 & -0.058 \\
\hline & $(-0.27)$ & $(-0.10)$ & $(-0.14)$ \\
\hline \multirow[t]{2}{*}{ central } & 0.161 & 0.169 & 0.127 \\
\hline & $(0.50)$ & $(0.53)$ & $(0.40)$ \\
\hline \multirow[t]{2}{*}{ sect_tech } & -0.338 & -0.026 & 0.256 \\
\hline & $(-0.21)$ & $(-0.02)$ & $(0.15)$ \\
\hline \multirow[t]{2}{*}{ sect_energy } & 3.099 & 2.954 & 3.239 \\
\hline & $(1.42)$ & $(1.34)$ & $(1.45)$ \\
\hline \multirow[t]{2}{*}{$=$ cons } & $6.358 * * *$ & $6.407 * * *$ & $7.672^{* * *}$ \\
\hline & $(3.28)$ & $(3.21)$ & (3.97) \\
\hline $\mathrm{N}$ & 595 & 595 & 595 \\
\hline R-Square & 0.1461 & 0.1345 & 0.1246 \\
\hline Log likelihood & -231.4073 & -234.5678 & -237.2392 \\
\hline
\end{tabular}

\section{DISCUSSION AND CONCLUSIONS}

Based on institutional theory (Barney, Wright, \& Ketchen Jr, 2001; North, 1990; Peng et al., 2009) and the springboard perspective (Luo \& Tung, 2007), we explore the factors affecting the LOF suffered by EMNCs in the context of the pre-CBMA stage. We propose two dimensions of institutional factors that underlie LOF, not only for the purpose of unpacking the black box of LOF, but also to explore contingent strategies to tackle these factors. Both static and dynamic perspectives are employed to address the question in the context of Chinese multinational cases, and lead to the following findings: (1) In alignment with prior studies, we find that cultural distance does play a major role in causing EMNCs to suffer from LOF. Yet it is the sophistication of the formal institutions per se rather than the distance of laws or regulations that underpins the LOF plaguing EMNCs. (2) From a static perspective, firm characteristics like state-owned identity are not found to be significant in terms of increasing the adverse impact of LOF. But firms in the high-tech industry are more likely to be subject to additional regulatory scrutiny that may lead to the failure of CBMA. (3) From a dynamic perspective, we posit that the extent of vulnerability to LOF may change with the accumulation of experience. However, we found that prior international experience works well to mitigate cultural distance but reinforces the negative effects stemming from the complexity of local formal institutions.

Our research may be beneficial in three ways. First, it decouples the institutional sources of LOF into formal and informal dimensions, namely laws and culture. Our findings on the negative impact of law quality rather than the distance of laws or regulations contradict the existing literature (Dikova et al., 2010; Johanson \& Vahlne, 1977; Kostova \& Zaheer, 1999), possibly due to the fact that most similar studies were undertaken within the context of MNCs from developed countries (Denk et al., 2012), which is arguable different from that of EMNCs. Assume that EMNCs invest in developed markets as well as in the least developed country, which exhibit the same distance in 
terms of formal institutions, yet one is better and the other is worse than the EMNC's home country. The "distance of laws" and "the quality of laws" will then display different outcomes, i.e., the completion likelihood in the former case will be the same as between developed and least developed countries, while in the latter case investing in developed countries may result in a low completion rate, considering the negative impact of the regression results. Our results advocate the latter variable; the stereotyped and negative understandings of host countries may ruin EMNCs' institutional images and thus account for the failures of the EMNCs. Prior research (He \& Zhang, 2018; Herz \& Diamantopoulos, 2013) also shows that multinationals from relatively poor institutional environments will suffer exacerbated obstacles in their realization of CBMAs.

Second, we also applied organizational learning theory to the study of the effects of LOF. Theoretical pluralism, in contrast to a single theory, allows for the integrated study of various facets of a topic, which in turn enhances our understanding of it. To accomplish this, we explore the effect of experience on different drivers of LOF. Prior research has produced mixed empirical results as to the effect of experience on the performance of M\&A. Some have claimed a positive effect of cumulative M\&A experience (Fowler \& Schmidt, 1989; He \& Zhang, 2018), while others found a negative relationship (Hayward, 2002); some have argued that experience plays a role in less institutionally distant countries (Dikova et al., 2010) while others reported no significant effects (Zollo \& Singh, 2004). This study was based on a continuum of international experience that ranged from exact contextual experience to highly related contextual experience to distantly related contextual experience, corresponding to the patterns of FDI. This not only produces a clear picture of how different degrees of experience work but provides a robust means of testing the role of experience. The results show that prior international experience works well to mitigate cultural distance, but struggles to alleviate the negative effects stemming from local formal institutions. We justify the results by contending that firms can take the initiative to develop mimetic isomorphism, which has been shown to be an effective way to gain external legitimacy in a host country (Zaheer, 1995). The efforts they make to undertake mimetic behavior can help them better understand and to some extent overcome the culture differences. However, unlike culture, which comes down in one continuous line, laws, regulations and policies are more volatile, complicated and country-dependent, so that transferring knowledge from one country to another is not necessarily a valid move. Hence, similar contextual M\&A experience with highly complicated regulations could be incorrectly applied to the focal M\&A events, causing misleading or negative marginal effects (Haleblian \& Finkelstein, 1999). Our research may fill the gap in the extant studies and help reconcile ambiguities in the literature.

Third, we address the LOF theory from both static and dynamic perspectives. From the static perspective, some firm-inherent characteristics like industry are proved to have negative moderating effects on LOF. Interestingly, we did not find evidence indicating that state ownership exacerbates the negative effects of LOF, in contrast with the findings of Zhang et al. (2011). We argue that institutional changes are developed following the process of the pre-institutionalization stage to the theorization stage to the diffusion stage (Greenwood, Suddaby, \& Hinings, 2002), where the acquisitions by SOE are experiencing the theorization stage, suggesting that the hostile attitudes and practices toward SOEs are still being justified by regulatory agencies and are not being taken for granted (Li et al., 2017). The dynamic perspective responds partly to the call to enhance our understanding of the dynamics of LOF (Denk et al., 2012). Examining the question from both static and dynamic perspectives can also help to increase our knowledge of what can and cannot tackle the problems of LOF.

\section{MANAGERIAL IMPLICATIONS AND LIMITATIONS}

Our research findings have important implications for corporate managers. First, they should attach high importance to the initial stage of CBMA. If the transaction fails, the company will miss investment opportunities, release important information, experience a loss of reputation or credibility, and bear various negotiating costs, such as costs of legal and financial advisors. The accurate identification of LOF can help MNC managers select 
among different countries to invest in and increase the odds of successful completion of the case. Moreover, the correct measurement of the extent of LOF is also helpful for managers when assessing the comparative performances of subsidiaries in different countries.

Second, managers should take more precautions in relation to developed CBMA destinations. Despite the advantageous investment environment, developed countries may have stricter national security regulations, which in turn become legitimate excuses for protectionism. Advocates of protectionism assert that free-trade policies were responsible for the recent collapse of the world economy. Along with the trend towards de-globalization, the rise of emerging economies, particularly China, has caused hostile sentiments to prevail in Western communities that worry about being surpassed. The advocacy of the "China threat" is thus prevalent. Managers of emerging MNCs should seriously consider the sophistication and volatility of laws and regulations of the host country as a key driver of LOF, as past experience in similar settings can help mitigate culture distance but cannot tackle the negative effects of legal issues.

There are certainly some limitations to this research that would otherwise make it more convincing. Some variables have not been included in the models due to the unavailability of data. First, the frequency with which firms have undertaken FDI cannot be calculated correctly as the database only spans the period from 2005 to 2014; such calculation is clearly not plausible if activities before 2005 are overlooked. Second, the length of time during which a firm participates in CBMA is also a very important experience factor. The longer the operating time in the host country, the more experience or networks will be accumulated, and thus the greater the mitigation of LOF.

Funding: This study received no specific financial support.

Competing Interests: The authors declare that they have no competing interests.

Authors Contribution: Both authors contributed equally to the conception and design of the study.

\section{REFERENCES}

Abrahamson, E., \& Fombrun, C. J. (1994). Macrocultures: Determinants and consequences. Academy of Management Revierw, 19(4), 728-755. Available at: https://doi.org/10.5465/amr.1994.9412190217.

Balabanis, G., Diamantopoulos, A., Mueller, R. D., \& Melewar, T. C. (2001). The impact of nationalism, patriotism and internationalism on consumer ethnocentric tendencies. Journal of International Business Studies, 32(1), 157-175. Available at: https://doi.org/10.1057/palgrave.jibs.8490943.

Barney, J., Wright, M., \& Ketchen Jr, D. J. (2001). The resource-based view of the firm: Ten years after 1991. Journal of Management, 27(6), 625-641.

Bartlett, C. A., \& Ghoshal, S. (2000). Going global: Lessons from late movers. Reading, 1(3), 75-84.

Beach, W., \& Kane, T. (2008). Methodology; Measuring the 10 economic freedoms (PDF). Index of Economic Freedom, 12(1), 3955 .

Beckman, C. M., \& Haunschild, P. R. (2002). Network learning: The effects of partners' heterogeneity of experience on corporate acquisitions. Administrative Science Quarterly, 47(1), 92-124. Available at: https://doi.org/10.2307/3094892.

Boone, A. L., \& Mulherin, J. H. (2007). How are firms sold? The Journal of Finance, 62(2), 847-875. Available at: https://doi.org/10.2139/ssrn.642306.

Buckley, P. J., Clegg, L. J., Cross, A. R., Liu, X., Voss, H., \& Zheng, P. (2007). The determinants of Chinese outward foreign direct investment. Journal of International Business Studies, 38(4), 499-518.

Calhoun, M. A. (2002). Unpacking liability of foreignness: Identifying culturally driven external and internal sources of liability for the foreign subsidiary. Journal of International Management, 8(3), 301-321. Available at: https://doi.org/10.1016/s 1075-4253(02)00072-8.

Chakrabarti, A., \& Mitchell, W. (2016). The role of geographic distance in completing related acquisitions: Evidence from US. chemical manufacturers. Strategic Management Journal, 37(4), 673-694. Available at: https://doi.org/10.1002/smj.2366. 
Child, J., \& Rodrigues, S. B. (2005). The internationalization of Chinese firms: A case for theoretical extension? Management and Organization Reviere, 1(3), 381-410. Available at: https://doi.org/10.1111/j.1740-8784.2005.0020a.x.

Cuervo-Cazurra, A., Maloney, M. M., \& Manrakhan, S. (2007). Causes of the difficulties in internationalization. Journal of International Business Studies, 38(5), 709-725.

Cuervo-Cazurra, A., Inkpen, A., \& Musacchio, A. (2014). Governments as owners: State-owned multinational companies. Journal of International Business Studies, 45(8), 919-942.

Cui, L., \& Jiang, F. (2009). FDI entry mode choice of Chinese firms: A strategic behavior perspective. Journal of World Business, $44(4), 434-444$.

Delios, A., \& Beamish, P. W. (2001). Survival and profitability: The roles of experience and intangible assets in foreign subsidiary performance. Academy of Management Journal, 44(5), 1028-1038.

Denk, N., Kaufmann, L., \& Roesch, J.-F. (2012). Liabilities of foreignness revisited: A review of contemporary studies and recommendations for future research. Journal of International Management, 18(4), 322-334. Available at: https://doi.org/10.1016/j.intman.2012.07.001.

Dikova, D., Sahib, P. R., \& Van Witteloostuijn, A. (2010). Cross-border acquisition abandonment and completion: The effect of institutional differences and organizational learning in the international business service industry, 1981-2001. Journal of International Business Studies, 41(2), 223-245. Available at: https://doi.org/10.1057/jibs.2009.10.

DiMaggio, P., \& Powell, W. W. (1983). The iron cage revisited: Collective rationality and institutional isomorphism in organizational fields. American Sociological Revierw, 48(2), 147-160.

Dixit, A. K., \& Pindyck, R. S. (1994). Investment under uncertainty. Princeton, New Jersey: Princeton University Press.

Doan, T. T., Rao, S. P., \& Van, W. A. (2016). The role of timing in a merger wave on overcoming challenges in the M\&A premerger process. Academy of Management Proceedings., $2016(1), 14545$.

Doan, T. T., Sahib, P. R., \& van Witteloostuijn, A. (2018). Lessons from the flipside: How do acquirers learn from divestitures to complete acquisitions? Long Range Planning, 51(2), 252-266. Available at: https://doi.org/10.1016/j.lrp.2018.01.002.

Dunning, J. H. (1979). Explaining changing patterns of international production: In defence of the eclectic theory. Oxford Bulletin of Economics and Satistics, 41(4), 269-295.

Edelman, L. B. (1990). Legal environments and organizational governance: The expansion of due process in the American workplace. American Journal of Sociology, 95(6), 1401-1440.

Eden, L., \& Miller, S. R. (2001). Opening the black box: The multinational enterprise and the costs of doing business abroad [C ] II Nagao D H (pp. C1-C6). Washington, DC: Academy of Management Meeting.

Eden, L., \& Miller, S. R. (2004). Distance matters: Liability of foreignness, institutional distance and ownership strategy. Advances in International Management, 16(4), 187-221.

Fiol, C. M., \& Lyles, M. A. (1985). Organizational learning. Academy of Management Review, 10(4), 803-813.

Fowler, K. L., \& Schmidt, D. R. (1989). Determinants of tender offer post-acquisition financial performance. Strategic Management Journal, 10(4), 339-350.

Greenwood, R., Suddaby, R., \& Hinings, C. R. (2002). Theorizing change: The role of professional associations in the transformation of institutionalized fields. Academy of Management journal, 45(1), 58-80. Available at: https://doi.org/10.5465/3069285.

Haleblian, J., \& Finkelstein, S. (1999). The influence of organizational acquisition experience on acquisition performance: A behavioral learning perspective. Administrative Science Quarterly, 44(1), 29-56. Available at: https://doi.org/10.2307/2667030.

Hayward, M. L. (2002). When do firms learn from their acquisition experience? Evidence from 1990 to 1995. Strategic Management Journal, 23(1), 21-39. Available at: https://doi.org/10.1002/smj.207.

He, X., \& Zhang, J. (2018). Emerging market MNCs' cross-border acquisition completion: Institutional image and strategies. Journal of Business Research, 93(4), 139-150. 
Hedberg, B. (1981). How organizations learn and unlearn in Handbook of organizational design $[M]$. Nystrom and W. Starbuck(eds.). Oxford: Oxford University Press.

Henisz, W. J., \& Williamson, O. E. (1999). Comparative economic organization-within and between countries. Business and Politics, 1(3), 261-277. Available at: https://doi.org/10.1515/bap.1999.1.3.261.

Herz, M. F., \& Diamantopoulos, A. (2013). Activation of country stereotypes: Automaticity, consonance, and impact. Journal of the Academy of Marketing Science, 41(4), 400-417.

Hymer, S. H. (1960). The international operations of national firms, a study of direct foreign investment. Doctoral Dissertation, Massachusetts Institute of Technology.

Jemison, D. B., \& Sitkin, S. B. (1986). Acquisitions-the process can be a problem. Harvard Business Review, 64(2), $107-116$.

Johanson, J., \& Vahlne, J.-E. (1977). The internationalization process of the firm-a model of knowledge development and increasing foreign market commitments. Journal of International Business Studies, 8(1), 23-32. Available at: https://doi.org/10.1057/palgrave.jibs.8490676.

Johanson, J., \& Vahlne, J.-E. (2009). The Uppsala internationalization process model revisited: From liability of foreignness to liability of outsidership. Journal of International Business Studies, 4O(9), 1411-1431.

Kogut, B., \& Singh, H. (1988). The effect of national culture on the choice of entry mode. Journal of International Business Studies, 19(3), 411-432.

Kolstad, I., \& Wiig, A. (2012). What determines Chinese outward FDI? Journal of World Business, 47(1), 26-34.

Kostova, T., \& Zaheer, S. (1999). Organizational legitimacy under conditions of complexity: The case of the multinational enterprise. Academy of Management Review, 24(1), 64-81.

Levitt, B., \& March, J. G. (1988). Organizational learning. Annual Review of Sociology, 14(1), 319-338.

Li, H., Meng, L., Wang, Q., \& Zhou, L.-A. (2008). Political connections, financing and firm performance: Evidence from Chinese private firms. Journal of Development Economics, 87(2), 283-299.

Li, J., Xia, J., \& Lin, Z. (2017). Cross-border acquisitions by state-owned firms: How do legitimacy concerns affect the completion and duration of their acquisitions? Strategic Management Journal, 38(9), 1915-1934. Available at: https://doi.org/10.1002/smj.2609.

Luo, Y., \& Tung, R. L. (2007). International expansion of emerging market enterprises: A springboard perspective. Journal of International Business Studies, 38(4), 481-498.

Meyer, K. E., Estrin, S., Bhaumik, S. K., \& Peng, M. W. (2009). Institutions, resources, and entry strategies in emerging economies. Strategic Management Journal, 30(1), 61-80. Available at: https://doi.org/10.1002/smj.720.

Mezias, J. M. (2010). Identifying liabilities of foreignness and strategies to minimize their effects: The case of labor lawsuit judgments in the United States. Strategic Management Journal, 23(3), 229-244.

Miller, S. R., \& Eden, L. (2006). Local density and foreign subsidiary performance. Academy of Management Journal, 49(2), 341355.

Morck, R., Yeung, B., \& Zhao, M. (2008). Perspectives on China's outward foreign direct investment. Journal of International Business Studies, 39(3), 337-350.

Morosini, P., Shane, S., \& Singh, H. (1998). National cultural distance and cross-border acquisition performance. Journal of International Business Studies, 29(1), 137-158.

Muehlfeld, K., Sahib, P. R., \& Van Witteloostuijn, A. (2007). Completion or abandonment of mergers and acquisitions: Evidence from the newspaper industry, 1981-2000. Journal of Media Economics, 20(2), 107-137.

Muehlfeld, K., Rao Sahib, P., \& Van Witteloostuijn, A. (2012). A contextual theory of organizational learning from failures and successes: A study of acquisition completion in the global newspaper industry, 1981-2008. Strategic Management Journal, 33(8), 938-964.

Newburry, W., Gardberg, N. A., \& Belkin, L. Y. (2006). Organizational attractiveness is in the eye of the beholder: The interaction of demographic characteristics with foreignness. Journal of International Business Studies, 37(5), 666-686.

North, D. C. (1990). Institutions, institutional change and economic performance. Cambridge: Cambridge university press,. 
Peng, M. W., Sun, S. L., Pinkham, B., \& Chen, H. (2009). The institution-based view as a third leg for a strategy tripod. Academy of Management Perspectives, 23(3), 63-81. Available at: https://doi.org/10.5465/amp.2009.43479264.

Pogrebnyakov, N., \& Maitland, C. F. (2011). Institutional distance and the internationalization process: The case of mobile operators. Journal of International Management, 17(1), 68-82. Available at: https://doi.org/10.1016/j.intman.2010.12.003.

Porter, M. E. (1980). Competitive strategy. New York: Free Press.

Rui, H., \& Yip, G. S. (2008). Foreign acquisitions by Chinese firms: A strategic intent perspective. Journal of World Business, 43(2), 213-226. Available at: https://doi.org/10.1016/j.jwb.2007.11.006.

Scott, W. R. (1995). Institutions and organizations. Thousand Oaks, CA: Sage.

Sethi, D., \& Guisinger, S. (2002). Liability of foreignness to competitive advantage: How multinational enterprises cope with the international business environment. Journal of International Management, 8(3), 223-240.

Singh, A. (2002). Competition and competition policy in emerging markets: International and developmental dimensions. London: Edward Elgar.

Very, P., \& Schweiger, D. M. (2001). The acquisition process as a learning process: Evidence from a study of critical problems and solutions in domestic and cross-border deals. Journal of World Business, 36(1), 11-31. Available at: https://doi.org/10.1016/s1090-9516(00)00052-3.

Wan, K.-M., \& Wong, K.-f. (2009). Economic impact of political barriers to cross-border acquisitions: an empirical study of CNOOC's unsuccessful takeover of Unocal. Journal of Corporate Finance, 15(4), 447-468.

Wier, P. (1983). The costs of antimerger lawsuits: Evidence from the stock market. Journal of Financial Economics, 11(1-4), 207224.

Yang, X., Jiang, Y., Kang, R., \& Ke, Y. (2009). A comparative analysis of the internationalization of Chinese and Japanese firms. Asia Pacific Journal of Management, 26(1), 141-162.

Zaheer, S. (1995). Overcoming the liability of foreignness. Academy of Management Journal, 38(2), 341-363. Available at: https://doi.org/10.5465/256683.

Zaheer, S., \& Mosakowski, E. (1997). The dynamics of the liability of foreignness: A global study of survival in financial services. Strategic Management Journal, 18(6), 439-463.

Zhang, J., Zhou, C., \& Ebbers, H. (2011). Completion of Chinese overseas acquisitions: Institutional perspectives and evidence. International Business Review, 20(2), 226-238.

Zhou, C., Xie, J., \& Wang, Q. (2016). Failure to complete cross-border M\&As: “to" vs. “from” emerging markets. Journal of International Business Studies, 47(9), 1077-1 105. Available at: https://doi.org/10.1057/s41267-016-0027-y.

Zollo, M. (2009). Superstitious learning with rare strategic decisions: Theory and evidence from corporate acquisitions. Organization Science, 20(5), 894-908. Available at: https://doi.org/10.1287/orsc.1090.0459.

Zollo, M., \& Singh, H. (2004). Deliberate learning in corporate acquisitions: Post-acquisition strategies and integration capability in US bank mergers. Strategic Management Journal, 25(13), 1233-1256.

Views and opinions expressed in this article are the views and opinions of the author(s), Asian Development Policy Review shall not be responsible or answerable for any loss, damage or liability etc. caused in relation to/arising out of the use of the content. 